\title{
The Research of Chinese Training Mode of Work-Study Combination
}

\author{
based on Foreign Mode \\ Fang Chen"1, a, Li Zhu², b, Lei Pan, c \\ ${ }^{1}$ Chongqing Normal University, Chongqing 400700, China; \\ ${ }^{2}$ Chongqing Electromechanical Vocational Institute, Chongqing 402760, China; \\ ${ }^{3}$ WenShan University, Yunnan 663000, China. \\ a49403591@qq.com, b17007811@qq.com, cpanlei928119@163.com
}

\begin{abstract}
Through the introduction of the German dual system, British sandwich program and the American cooperative education of the talent training mode of work-study combination, it indicates the features the foreign model of combination of working with learning. On the analysis of the deficiency and shortcuts of talent training mode of work-study combination in our country, learning from foreign successful model, it proposes relevant measures to improve the talent training mode of work-study combination in our country through the perspective of government, universities and enterprises.
\end{abstract}

Keywords: Training mode of work-study combination; talent cultivation; vocational education.

\section{Introduction}

"Talent training mode of work-study combination" is refers to the combination of student's study and work. Oriented to career, it takes the improvement of students' employment competitiveness as the purpose and takes a wide range of social market needs as a platform to fully use two kinds of teaching resources, education environment of schools and businesses and combines off campus work which directly obtains experiences with school education which focuses on the classroom teaching, which will exist through students' whole talent training work [1].

\section{Training Mode of Work Study Combination in Foreign Countries}

Throughout the understanding of training mode in developed countries, it mostly highlights the characteristics of combination of working and learning, such as German dual system mode, the British sandwich education, Cooperative education mode in the United States and Canada, Japanese study and production cooperation mode and Australia TAFE mode as the industry leading and so on. Their experience highlights the advantages of the combination of work and study mode, and seriously studying the characteristics and successful experience of the combination of work and study in developed countries can greatly promote the cultivation of talents in our country.

\subsection{German Dual System Mode.}

German dual system education, refers to both the theoretical knowledge and practical skills learning in school and professional knowledge studying in enterprises. It is mainly based on enterprises, schools play as a supporting role, and the teaching is also practice-based, supplemented by theory. Trainees takes $1 / 3$ time in the school to accept the theory of teaching, the remaining $2 / 3$ time in the enterprise training [1]. Its theoretical and practical teaching arrangements are in the three forms, as shown in figure 1. 


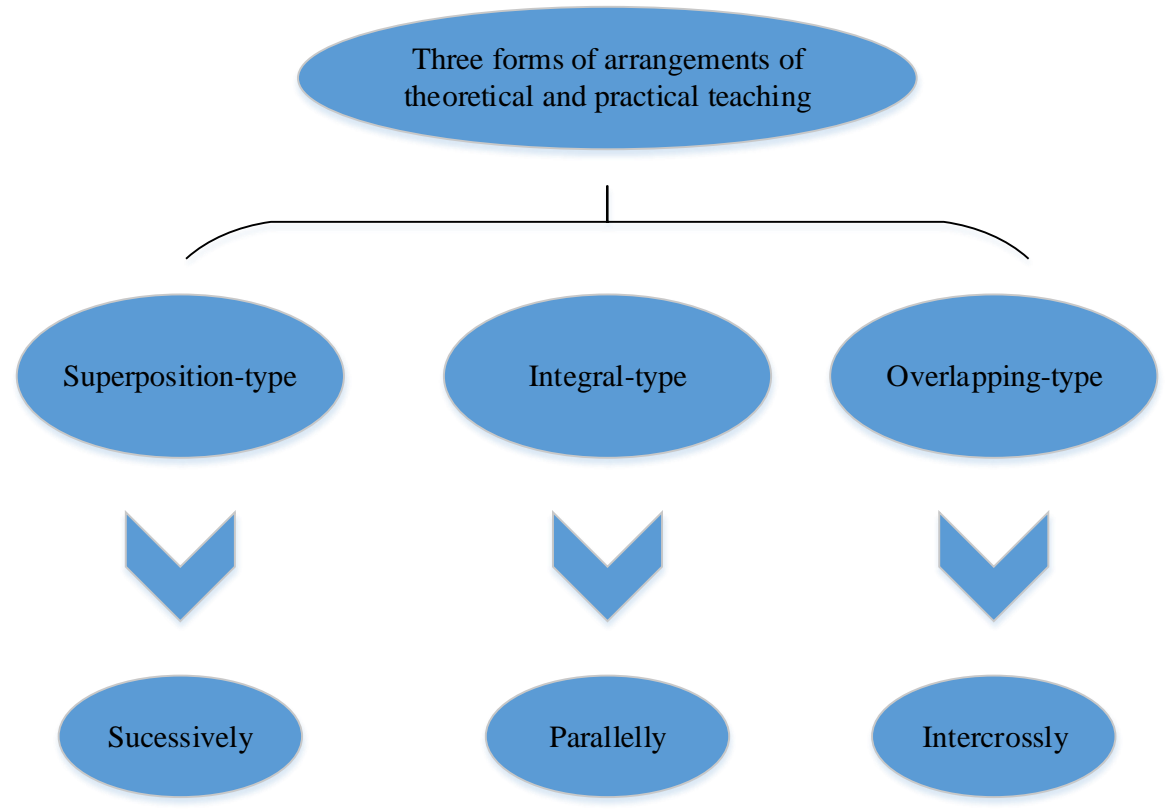

Figure 1 Three forms of arrangements of theoretical and practical teaching

\subsection{British Sandwich Education Model.}

Sandwich education mode is adopted in the United Kingdom study practice learning, combined with the sandwich production mode of teaching. The sandwich type in the system arrangement is 1 year longer than the general degree courses, the more a year is used for work practice. In the teaching schedule, some of the school alternate by year while some by month.

\subsection{American Cooperative Education Mode.}

This mode first appeared in 1906. Its implementation regulations are: after half a year from the start of the learning tuition, the enterprise practical training and university teaching alternate by 2 months for students. And in the half a year before graduation, students are centralized to have lectures at the university and finally complete the graduation project. At present, the key to the development of engineering education mode in the developed countries is to arrange the working time of the students in order to achieve the goal of education internationalization. In June 2006, the World Association for Cooperative Education held the 2006 World Association for cooperative education mode in the Asia Pacific region Exchange Association, more than 130 participants from 23 countries in all continents unanimously stressed the significance of the internationalization of training mode of work study combination.

\section{Characteristics of Training Mode of Work Study Combination in Foreign Countries}

(1) Standard management. Many colleges and universities in Britain, the United States, Australia, Canada and other developed countries are equipped with specialized management departments, such as the University of Waterloo in Canada "Cooperative Education and Career Counseling Department" is one of the largest management institutions at the school, responsible for the entire school nearly 2 , 000 students off campus work arrangement and management

(2) Staff is equipped with emphasis on the "double division" structure. Most of the staffs in the management department are "double division" structure. More than half of the engineers from the enterprise, which plays an irreplaceable important role in the student work arrangement and management. In the construction of teaching system, most of these countries adopt the credit system and flexible system and students can arrange their own learning and work time, teaching activities flexibly [2]. 
(3) Flexible and varied curriculum. The courses of foreign universities are mostly modular structure. Students can choose the combination of modules in a certain extent. Schools divided students with the same grade and profession into two groups of the rotation of the course arrangement in order to meet the needs that a job should always have students work.

(4) Government support. Many developed countries with good vocational education through the development of relevant policies to encourage employers to accept students' practice, to encourage schools to implement work study combination of talent training mode. The most common for the former one is the tax rebate policy. The typical one is the tax rebate system in Ontario, Canada (Education Tax Credit Cooperative, referred to as CETC). The policy stipulates that the employer received a student internship, it can enjoy the corresponding tax treatment. The typical school encouragement policy is in the United States. It has promulgated many laws and draft in 30 years from 1965 to 1994 and has earmarked 17 times and the cumulative amount came to 2 million dollars. The result of such measures is that the implementation of the combination of engineering education mode of higher schools increased from 55 to more than 1100[3].

\section{Experience and Reference of the Training Mode of Work Study Combination in Foreign Countries}

How to draw lessons from foreign experience and combine with Chinese specific practice, choose a reasonable way to implement the combination of work and study personnel training mode, is the problem we need to solve at present.

In 2011, a school had a study researching on the status of the combination of work and study in our country, using the questionnaire survey to understand the attitude of the students to this new teaching mode. In the understanding of the combination of work and study, the results are shown as below. There is $66 \%$ students have a little understanding of the combination of work and study, only $22 \%$ of the students have a better understanding. Besides, $86 \%$ of the students hope to reform the traditional teaching mode which takes classroom teaching as the center and $54 \%$ of the students think that the lack of operational skills will affect their professional skills (Figure 2).

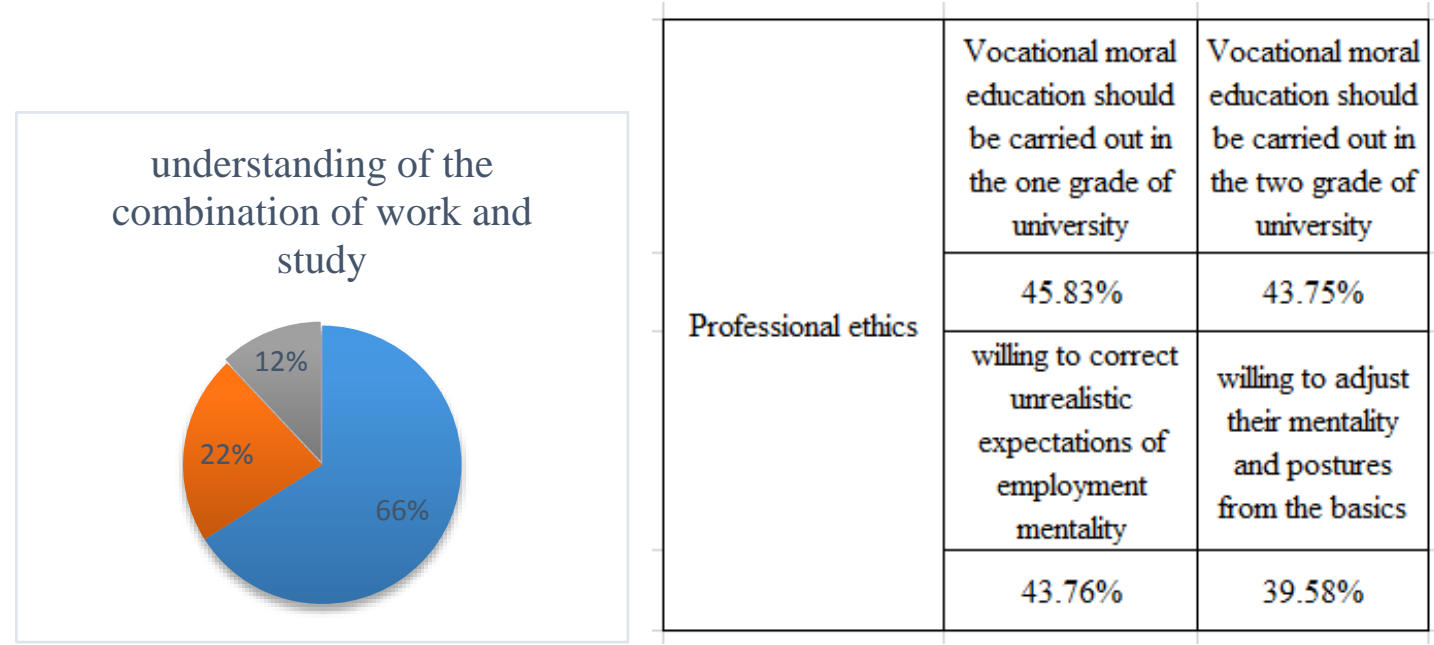

Figure 2 Understanding of the new teaching and professional ethics

As for the professional skills, students show strong consciousness to improve the professional skills hoping that through school practice and internship, it can improve their professional skills and 54\% of the students are not satisfied with their current skills. In professional ethics, the survey were indicated above [4].

From the survey results, it can be seen that students welcome the reform in traditional personnel training mode which sees classroom teaching as the center. It can strengthen the combination of 
teaching and practice. But in China the combination of talent training mode is facing multiple factors of shortage, manifested in the lack of management system, teaching system, curriculum system, the enthusiasm of enterprises and individuals. So foreign talent training mode provides a reference for China and the specific operations can be done as follows:

(1) First, the government must play an important role in vocational education. Government not only needs to increase investment, and should use legal, economic, administrative means and policy to guide and promote social and enterprises to participate in vocational education, which makes fully use of social forces and business organizations[5].

(2) Second, taking the needs of society as the basic orientation of the reform to implement the vocational curriculum setting. In this regard, it can learn from the experience of the United States, the United Kingdom, most of which are practical curriculums and they can reflect the latest achievements of scientific and technological progress.

(3) The third one is to strengthen the contact between industry and business and design the scheme of training according to the different professional requirements. It can learn from the British "sandwich" alternative mode. According to the alternative interval, it can take the school year, semester, month as the alternative system which is good for students to understand the theoretical knowledge, grasp the production skills and the production process. In summary, it should play the role of the government, universities, enterprise to implement its own responsibilities, respectively.

\section{Summary}

In a word, the research objective of foreign experience is to find references. To study the talent training mode of work study combination in our country, it must start from Chinese national conditions, especially the conditions of regional economic and social development to meet the social demand as the basic guide. It must correctly understand the meaning and purpose of training mode of work-study combination so as to establish a long-term operation mechanism by the combination of students, schools, enterprises and government and blaze a path of higher vocational education with Chinese characteristics.

\section{Acknowledgement}

Government funded project: 2014 Chongqing Educational Science Fund during the 12the Fiveyear plan.

\section{References}

[1] Huaiyong Wang. The research and practice of talent training mode of work study combination [D].Wuhan University of Technology, Hubei: Wuhan, 2009.

[2] Jianwei Lv, Gengshen Zhu, Hongyun Song, Wei Du, et al. Comparative analysis of talent training mode in Chinese and foreign research $(\mathrm{J})$. Science Technology and Industrialization of Chinese University, 2011 (04): 46-47.

[3] Jianwei Lv, Baojun Han. Core features and practical construction of talents training mode of work study combination [J]. Chinese University Technology Transfer, 2011 (01):57-58.

[4] Lixuan Wu. A comparative study on the talent training mode of Higher Vocational and technical education at home and abroad [J]. China Light Industry Education, 2011 (2): 70-73.

[5] Jun Wang. Reference of the mode of work study combination in foreign countries [J]. Chinese University Science and Technology, 2011 (11): 44-45. 